\title{
El hibridismo del villancico: la figura del pastor entre lo lírico y lo teatral

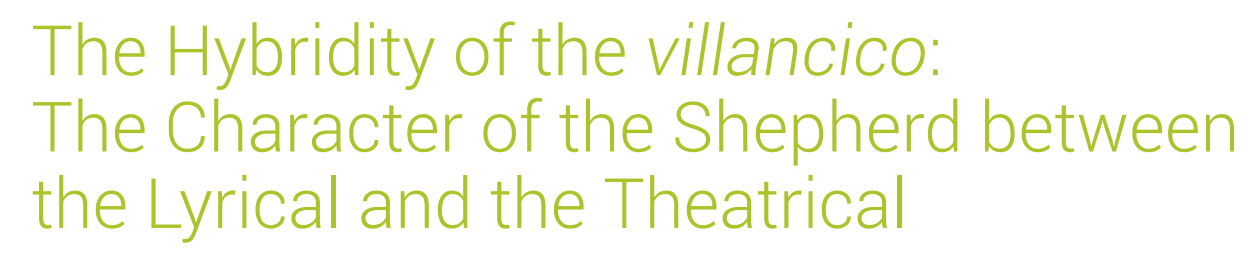

\section{Esther Borrego Gutiérrez}

http://orcid.org/0000-0002-4942-9372

Universidad Complutense de Madrid

ESPAÑA

eborrego@ucm.es

[Hipogrifo, (issn: 2328-1308), 9.1, 2021, pp. 101-129]

Recibido: 03-11-2020 / Aceptado: 03-03-2021

DOI: http://dx.doi.org/10.13035/H.2021.09.01.08

Resumen. El personaje del pastor mantiene una fuerte presencia en el villancico religioso barroco, cuyo auge tuvo lugar en el siglo XVII y en una buena parte del XVIII. En esta figura confluyen varios tipos líricos y teatrales procedentes de las obras de Juan del Encina y de otros autores cercanos en el tiempo. Se pretende romper el tópico de que el pastor cómico, materialista y glotón fue el que pasó a entremeses y villancicos, abordando una tipología del personaje que entronca con el pastor primitivo rústico, en su vertiente más cómica y cercana a lo teatral o en su caracterización lírica de inspiración culta.

Palabras clave. Villancico religioso barroco; entremeses; Juan del Encina; pastor rústico; Pastor evangélico; pastor culto; literatura religiosa.

Abstract. The character of the shepherd maintains a strong presence in the Baroque religious villancico, whose heyday took place in the 17th century and in a good part of the 18th century. In this character, several lyrical and theatrical types come together from the works of Juan del Encina and other authors close in time. It is intended to break the cliché that the comic, materialistic and gluttonous shepherd was the one who went to entremeses and villancicos, addressing a typology 
of the character that is more closely related to the primitive rustic shepherd, in its most comic aspect and close to the theatrical or in its lyrical characterization of cultured inspiration.

Keywords. Baroque religious villancico; Entremeses; Juan del Encina; Rustic pastor; Evangelical pastor; Cultured pastor; Religious literature.

Para Álvaro Alonso, con gratitud y admiración de siempre

En otros trabajos he dedicado mi atención a los diversos tipos del villancico religioso barroco, género popular en su tiempo aunque apenas incluido en el canon, que ha sido recuperado por la crítica en las dos últimas décadas ${ }^{1}$. La tipología del villancico se ve condicionada en gran parte por el mayor o menor peso de lo lírico y lo teatral, del texto monologado o dialogado 2 . Pretendo afrontar aquí, tomando como eje una figura de amplia tradición literaria, el pastor, la sinuosa frontera entre lo lírico y lo teatral en un género híbrido por naturaleza, dada la fusión de los componentes literario y musical y de su diversidad de temas, formas y destinatarios. Siempre en verso y siempre cantado, sus formas métricas combinaron la inspiración culta con la popular, sus temas fueron ora teológicos ora cancioneriles, y sus tramas, en los de índole más teatral, muy cercanas al ámbito del refranero, de la cuentística y del teatro cómico breve de la época. Como es sabido, entre finales del siglo XVI y mediados del XVIII, el villancico gozó de una amplia aceptación popular, dado su carácter festivo y en muchas ocasiones cercano a lo teatral. Su inserción en la liturgia navideña, del Corpus o de alguna fiesta mariana o hagiográfica hacía las delicias del feligrés de su tiempo, que inesperadamente se convertía en espectador de unas piezas musicales y literarias que deleitaban por su lirismo o provocaban la risa por la presencia de personajes folklóricos o de honda tradición en los géneros jocosos de nuestra literatura ${ }^{3}$.

A través de mis amplias lecturas de villancicos puedo constatar que es un hecho la omnipresencia de la figura del pastor en los villancicos barrocos navideños y de Epifanía, donde recuperaba su doble origen: el evangélico y el literario, sobre todo teatral, con su enorme carga festiva. Como es sabido, el pastor fue uno de los primeros personajes, por no decir el primero, de nuestro teatro, pues protagonizó los tropos medievales del Officium Pastorum, indisolublemente unidos a los textos

\footnotetext{
1. Este auge en el estudio del villancico se debe tanto a musicólogos (ver Bombi, 2019, Torrente, 2000a, 2000b, 2007, 2016; Knighton y Torrente, 2007; Bombi, Carreras y Marín, 2005; Laird, 1997; Rodríguez, 1996-1997, 1997-1998 y 2003; Caballero Fernández-Rufete, 2004, entre otros) como a filólogos (ver Bègue, 2007 y 2010; Llergo, 2017; López Guil, 2011; Tomassetti, 2008; Borrego, 2012, 2013, 2018, 2019 y Borrego y Marín, 2019, entre otros)

2. Para la tipología del villancico, ver Bègue, 2007 y Borrego, 2019.

3. Para una taxonomía de los personajes del villancico, ver Borrego 2019.
} 
evangélicos, sobre todo de San Lucas, donde se relata el Nacimiento de Jesús y la adoración de los pastores ${ }^{4}$. El pastor primitivo poseía una fe y una bondad innata para comprender los misterios de la Natividad e ir a adorar al Niño, y así figura en la tradición pastoril castellana, representada en piezas navideñas de Gómez Manrique o Fray íñigo de Mendoza ${ }^{5}$, por ejemplo. Sin embargo, poetas que frisan ya un incipiente Renacimiento, como Juan del Encina y Lucas Fernández, minimizan esos rasgos evangélicos acercándose más al sustrato profano y festivo de nuestro primitivo teatro y acentúan, en algunos casos, su condición de personajes rudos y de baja ralea social, atribuyéndoles vicios como la pereza, la glotonería y la zafiedad, lo que no es incompatible con la presencia en sus obras de otros pastores inocentes, rústicos pero cultos, propios de églogas o de villancicos dialogados que

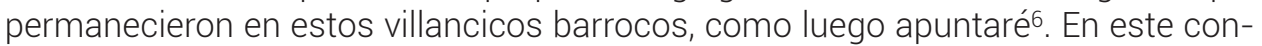
texto, es cierto que el personaje evoluciona desvirtuando su candor y maleándose para sobrevivir en entornos urbanos, como en el Auto del repelón (en torno a 1498) de Encina, en el que dos pastores rústicos vencen al estudiante, adquiriendo sus mismas mañas tras haber sido burlados por él. También está presente la burla en la Égloga de Antruejo (en torno a 1494), esta sí de ambiente carnavalesco, protagonizada igualmente por estudiantes y pastores. El gran rival y émulo de Encina, Lucas Fernández, nos trae asimismo en sus Farsas y églogas (1514) piezas navideñas con un protagonismo pastoril ya muy despegado de su origen, pues el rústico zagal se perfila como el bobo o simple, personaje que encarna la comicidad por antono-

4. «Había pastores en la misma región, que velaban y guardaban las vigilias de la noche sobre su rebaño. Y he aquí, se les presentó un ángel del Señor, y la gloria del Señor los rodeó de resplandor; y tuvieron gran temor. Pero el ángel les dijo: No temáis; porque he aquí os doy nuevas de gran gozo, que será para todo el pueblo: que os ha nacido hoy, en la ciudad de David, un Salvador, que es Cristo, el Señor. Esto os servirá de señal: Hallaréis al niño envuelto en pañales, acostado en un pesebre. [...] Sucedió que cuando los ángeles se fueron de ellos al cielo, los pastores se dijeron unos a otros: Pasemos, pues, hasta Belén, y veamos esto que ha sucedido, y que el Señor nos ha manifestado. Vinieron, pues, apresuradamente, y hallaron a María y a José, y al niño acostado en el pesebre. Y al verlo, dieron a conocer lo que se les había dicho acerca del niño. Y todos los que oyeron, se maravillaron de lo que los pastores les decían. [...] Y volvieron los pastores glorificando y alabando a Dios por todas las cosas que habían oído y visto, como se les había dicho» (Lucas, 2, 8-20).

5. En fray Îñigo de Mendoza ya sí se da la fusión del pastor evangélico-navideño con los rasgos de tosquedad cómica de la figura folklórica. De hecho, él mismo lo dice: «pues razón fue declarar / estas chufas de pastores / para poder recrear, / despertar y renovar / la gana de los lectores» (Mendoza, Cancionero, p. 55). Es significativo un texto reprobatorio del clérigo Juan de Padilla que demuestra que la comicidad del personaje debía de tener ya cierta difusión: «Nótese mucho por mal peligroso, / queriendo en las cosas de Cristo decir, / apócrifas chufas que hagan reír» (apud. Asensio, 1949). De estas palabras se deduce la clara condena de esta convergencia de la inocencia del pastor navideño con la comicidad burda del folklórico. Debo todas las precisiones de esta nota a Álvaro Alonso. Asimismo, quiero agradecer y consignar su ayuda en los contenidos concretos de las notas 23,25 y 34, así como su asesoramiento en el planteamiento general de mi trabajo.

6. Para la caracterización de los pastores de Juan del Encina y sus fuentes, ver Bustos, 2014. El estudioso rompe con los tópicos sobre los orígenes folklóricos y carnavalescos del pastor y demuestra la doble inspiración enciniana: la lírica cancioneril y la comedia toscana, con remotas raíces virgilianas. Profundiza sobre tales inspiraciones humanísticas, en especial italianas, también de modo magistral, Álvaro Alonso, 2012 y 2014. 
masia $^{7}$ y que evolucionará hasta llegar al gracioso de nuestro teatro áureo, ya sea el gracioso entremesil o el de las comedias y tragedias de nuestros clásicos. Otros autores como Gil Vicente o Diego Sánchez de Badajoz (con enfoques bien distintos, por cierto) siguen en esta línea de pastores zánganos y mordaces, muy lejos de cualquier bucolismo. Sin embargo, Lope de Rueda, considerado ya en su época como el padre del entremés, al someter sus Pasos a una progresiva urbanización apenas introduce en sus piezas pastores como tales, consagrando al bobo o simple como el motor cómico del incipiente género teatral breve, pero ya escindido de su origen pastoril. En cuanto a los entremesistas del XVII, tan solo mencionaremos la ausencia del pastor en los entremeses cervantinos y su escasa presencia en la obra del gran Quiñones de Benavente. En cuanto al resto de entremesistas, podemos resumir calificando la presencia del pastor (y la pastora) como escasa y dispersa, despojado ya el personaje de su inicial inocencia o simpleza 8 .

Por el contrario, el pastor sencillo de raíz evangélica permanecerá en el siglo XVII, si bien de modo testimonial (como interlocutor sin respuesta, por ejemplo) en villancicos de tipo lírico, que entroncan con el «villancico» entendido como la forma métrica estrófica fija (generalmente octosílabo o hexasílabo) que incluía copla y estribillo (un estribillo inicial más una estrofa o pie dividido en tres partes: dos mudanzas simétricas y una vuelta), que está presente en nuestra literatura desde el siglo $\mathrm{XV}^{9}$ y que fue precisamente Juan del Encina quien lo puso en boca de muchos de sus pastores. No olvidemos que fue en su Cancionero de 1496 donde el villancico, que él había definido como estrofa métrica en el apartado introductorio al mismo - Arte de poesía castellana-, es clasificado en «amoroso», «pastoril» o «de devoción» ${ }^{10}$. Otra figura que hay que incluir en estos apuntes sobre el origen del pastor villanciqueril es el pastor culto procedente de las novelas y poemas pastori-

7. Buen ejemplo de esto es la Farsa o cuasicomedia de la Doncella, el Pastor y el Caballero, en la que el pastor es caricaturizado grotescamente y muere de «cachondiez».

8. Debo hacer notar que el baile entremesado fue el género que acogió los escasos pastores de los entremeses del XVII. Citaré algunos títulos, como Bras y Menga y Los zarrapastrones, de Luis Quiñones de Benavente; Gila y Pascual y Pascual y Menga, de Juan Vélez de Guevara; el anónimo Pascual y Gileta (incluido en el libro de bailes El juego del hombre), y Gila y Pascual, zagales, de Vicente Suárez de Deza. No está de más recordar que la pareja Gil-Pascuala (en este caso invertido el género) ya está presente en Juan del Encina (Égloga de Mingo, Gil y Pascuala). Las tramas argumentales giran en torno a los desencuentros amorosos de pastores y pastores con los consiguientes celos de unos y otras, asunto que apenas aparece en nuestros villancicos.

9. Quizá hay que precisar aquí, como ya he hecho otras veces (ver Borrego, 2013, p. 27), el triple sentido del término villancico en la crítica literaria actual: 1) villancico profano de los siglos XV y XVI (que llegó hasta el XVII), entendido como la citada forma poética, heredero del zéjel y emparentado con el virelai francés: Juan del Encina es autor de varios de este tipo; 2) villancico barroco o paralitúrgico, antes definido y objeto de este artículo; 3) villancico popular navideño, que ha sobrevivido hasta la época actual y ha sido objeto de diversas recopilaciones.

10. Encina dignifica el villancico popular, al que confiere rasgos cultos, prefiriéndolo sobre la forma culta de la canción lírica cortés. Un villancico cerraba las églogas navideñas y se hizo costumbre en los palacios de los nobles, como se hacía en la iglesia. Por otra parte, según Bustos, «en la sección de villancicos de pastores está, in nuce, el germen de su teatro, también del elemento cómico [...] ese apego [a los pastores] es seña de identidad» (2014, pp. 19, 23). 
les del siglo XVI, con raíces remotas en Virgilio y más cercanas en Sannazaro, que también es fuente de la obra enciniana y que dará su juego en el villancico religioso barroco, sobre lo que enseguida volveré.

Así las cosas, no se puede negar que los pastores de nuestros villancicos conservan ciertos rasgos de zafiedad cómica atribuibles al simple, por supuesto, y así lo mostraremos, pero hay que apuntar que tales peculiaridades suelen presentarse matizadas, pues estos personajes se adaptan a la situación comunicativa, es decir, al contexto de la Navidad y la Epifanía, con la consiguiente adoración de los pastores en el primer entorno, y de los Reyes en el segundo. De este modo, los pastores, de tan larga tradición literaria, se convierten (o reconvierten, según se vea) generalmente en los pastores evangélicos que fueron a adorar al Niño y a llevarle presentes. Pero no todo es tan uniforme. Digamos que este personaje se enriquece en los villancicos y es capaz de desdoblarse como tal, presentando un amplio arco de comportamientos y funciones, que van desde el pastor idealizado y culto hasta el pastor zafio presente en las farsas renacentistas, pasando por el sencillo pastor evangélico. Tampoco hay que olvidar a su homóloga femenina, la pastora, con la que muchas veces actúa en pareja, pero otras sale ella sola o acompañada de otra(s) pastora(s) y que también ofrece diversos registros, desde el más culto al más elemental. Así, podríamos delimitar tres tipos básicos de pastor villanciqueril ${ }^{17}$ :

1) el pastor rústico, con destacados rasgos cómicos, si bien matizados por el entorno navideño;

2) el pastor que se define por su participación en la escena navideña (adorador, portador de regalos, espectador, etc.), de raíz evangélica, cuya función no es directamente cómica ${ }^{12}$;

3) el pastor lírico, que parte del modelo idealizado o culto, que funciona a modo de estereotipo literario y que se relaciona con los géneros pastoriles de los siglos XVI y XVII, de gran difusión editorial: él será el que cante preciosos versos líricos al Niño, desdibujando por completo su origen y su oficio. Pero, como veremos, ese lirismo admite gradación, pues tenemos pastores con una expresión más culta o literaria y otros más populares pero no por eso menos líricos, que se acercan a los del anterior apartado.

Respecto al pastor cómico con un mayor o menor peso de rasgos cercanos a lo teatral, hay que subrayar que no se trata de un personaje plano y repetitivo: el género del villancico confirió a estos pastores el protagonismo que el teatro breve barroco les negó y abrió las puertas a una originalidad creadora en la construcción de

11. Respecto a la pastora, básicamente responde a los tres tipos, pero con las peculiaridades que le confiere su femineidad.

12. Llergo diseña una tipología del pastor en la que en los dos extremos estarían el pastor cómico entremesil y el pastor idealizado, para apuntar lo que ella denomina el «punto medio»: "Se trata de un pastor rústico y humilde que, sin embargo, no está ideado para suscitar comicidad, sino que su ignorancia y simpleza son valoradas positivamente como indicativos de un corazón puro dispuesto a amar de forma sincera al Niño» (Llergo, 2017, p. 370). Como se ve, aquí matizo los extremos y dedico una atención particular al tipo de pastor más común, el que he denominado «evangélico», definido por su contexto y con una amplia funcionalidad. 
determinados personajes fijos, que pasaban de unos villancicos a otros con toda naturalidad, digamos que hasta de un modo metaliterario ciertamente moderno ${ }^{13}$ : Gil, Antón, Bras, Bato, Bartolo, Pascual, etc. son pastores habituales en decenas de piezas. Una de las parejas más habituales fue la formada por Bras y Menga, hasta el punto de que encontramos a la altura de 1678 alusiones a sus disputas en villancicos «antiguos»:

Bras, aquel pastor antiguo,

que contra su Menga ingrata,

en armoniosas quejas

Iloró mil coplas cantadas,

esta noche se aparece

en Belén, de donde saca

a sus zagales a paso

de baile de sus cabañas (CR: N1678, VI) ${ }^{14}$.

Y es que estas disputas vienen de muchos años atrás:

Pastores y pastoras

vienen al lugar,

que dicen que ha nacido

el sol en un portal.

Por todos y por todas

el bien venido dan

Gilota, la garrida,

con el polido Bras.

[...]

[MENGA] Bras, pus tenéis tanta cencia,

a resquebrarle espenzad.

[BRAS] Vos, Menga, harés, mas mijor, todo lo que huere habrar.

13. Quizá fuera el mismo Juan del Encina el primero en explotar esa metateatralidad, aunque de manera incipiente: «El salmantino explotó constantemente esa función metaliteraria del pastor en sus villancicos pastoriles y en sus piezas dramáticas: la comicidad de este tipo de recurso alegórico es muy patente y no debe ser vista despectivamente como un rasgo «medievalizante» o folklórico, sino típicamente humanista y renovador» (Bustos, 2014, p. 20)

14. He seleccionado un amplio corpus de villancicos para acometer este trabajo. En concreto, todos los que se conservan del siglo XVII ejecutados en la Capilla Real (1641-1700), en el Monasterio de las Descalzas Reales (1678-1700) y en el Convento de la Encarnación (1671-1700), que suman un total de 1046 y se contienen en 132 pliegos (ver Borrego, 2019, p. 60). El pliego era el formato habitual de impresión de estas piezas. Para las citas he abreviado los lugares donde se ejecutaron estas piezas: CR (Capilla Real), DR (Descalzas Reales) y E (Encarnación) y las fiestas para las que se destinaron: $\mathrm{N}$ (Navidad) y R (Reyes); a todas les sigue el año y el lugar que ocupa el villancico citado en el pliego. Salvo que apunte lo contrario, todos estos villancicos se conservan en la BNE, y son de fácil acceso a través de la Biblioteca Digital Hispánica (http://www.bne.es/es/Catalogos/BibliotecaDigitalHispanica/ Inicio/index.html). Para este corpus, ver Borrego, 2018 y 2019. Para la transcripción de los textos he seguido un criterio de modernización ortográfica (grafías, tildes, puntuación), de acuerdo con las normas de la Real Academia Española, respetando siempre los términos de la época con relevancia fonética. 


\begin{tabular}{|c|c|}
\hline [MENGA] & $\begin{array}{l}\text { Él sea muy bienvenido, } \\
\text { que harto esperado le han. }\end{array}$ \\
\hline [BRAS] & $\begin{array}{l}\text { Ansí mos lo dijo el cura, } \\
\text { no sé en qué festividad. }\end{array}$ \\
\hline [MENGA] & $\begin{array}{l}\text { Por mueso amor dix que viene } \\
\text { a morir con mucho afán. }\end{array}$ \\
\hline [BRAS] & $\begin{array}{l}\text { Pardiobre }{ }^{15} \text {, que para eso, } \\
\text { que yo me quedara allá. }\end{array}$ \\
\hline [MENGA] & $\begin{array}{l}\text { Para todo es apañado } \\
\text { quien se lo ve aquí callar (CR: N1665, VII). }\end{array}$ \\
\hline
\end{tabular}

Pero parece que Bras no solo peleaba con Menga, pues también forma pareja discutidora con Gil en otra tanda de villancicos que debió de ser antigua, pues ya en 1651 se alude a ellos como «desterrados de los maitines» ${ }^{16}$ porque «destruyen Navidades» (por las disputas o por lo cansado de las mismas). Lo curioso, en otro ejercicio metaliterario, es que estos zagales son sustituidos por Sancho Panza reconvertido en pastor, ni más ni menos:
Si queréis tener, señores, la Navidad con primores, callen los Giles y Brases que destruyen Navidades. Vayan los Brases y Giles desterrados de maitines que persiguen los pastores. Niño de flores,
pues válida está la chanza, oigan al pastor Sancho Panza que viene a decirle amores. ¡Por allá, por allá van los Giles, que los echan de los maitines!

15. Pardiobre: Interjección antigua que significa «por Dios», proviene de «Par Dios, par diez» (Aut.). Forma parte del acervo léxico de la jerga villana llamada «sayagués», con su fonética propia. Se trata de un lenguaje propio de los villancicos, artificial y literaturizado: ver Bustos, 2014, pp. 30 y ss. Hay un único villancico en todo el corpus cuyo protagonista es precisamente un sayagués, con su habla peculiar: «¿Qué pergeño ni que caletre / mos enfosca con tal confusión, / viendo estrellas en medio del día / y de noche muy craro el sol? / ¿Qué digamos? / ¿Quién así nos enquillotró?» (E: R1683, II). Los villancicos de la Encarnación abundan en mixturas de personajes, como el pastor asturiano, el pastor portugués, etc. El primero es un personaje que merecería un estudio aparte, pues está presente desde la Navidad de 1680 hasta la de 1697, siempre en el último villancico del pliego, lugar que hasta 1679 ocupaba el personaje del negro. El asturiano es cómico por definición, ya sea por su tosquedad o por sus comentarios acerca de la política del momento.

16. Gil y Bras reaparecen en un villancico de la Encarnación de 1677 en el que se insiste en «desterrarlos» de los villancicos: «1. ¡Hola! Decidme, pastores / que al Niño Dios festejáis, / ¿cómo no ha venido Gil?, / ¿cómo no ha llegado Bras? / ¿Adónde están? / 2. Ya salieron desterrados / del pesebre y del portal [...] Yo so Gil, / el que al Niño Jesús acallaba / con la frauta y el tamboril. / Yo so Bras, / el que en todas las chanzonetas / era siempre la gracia y la sal» (E: N1677, III). 
¡Por allá, por allá van los Brases,

que destruyen Navidades!

¡Por aquí, por aquí va la danza,

oigan, oigan a Sancho Panza! ${ }^{17}$ (CR: N1651, III).

Ya muy a final de siglo parece que el estilo pastoril primitivo - «viejo»- está finiquitado, hasta el punto de que es el pastor Pascual el «archivo» de las seguidillas viejas ${ }^{18 .}$

Pascual, que es archivo andante

de las seguidillas viejas,

pues las sabe de memoria

para decirlas de apuesta,

alrededor de la lumbre

a todas las zagalejas

responde de donde diere,

porque habla, venga o no venga (N1695, VIII).

La presencia constante de estos personajes llegó a ser cansina ${ }^{19}$, lo que se refleja en este pasaje, ya de finales de siglo, donde se llega a distinguir, como iconos fijos, a los pastores simples, Gil y Bras, del resabiado e ingenioso Bartolo:

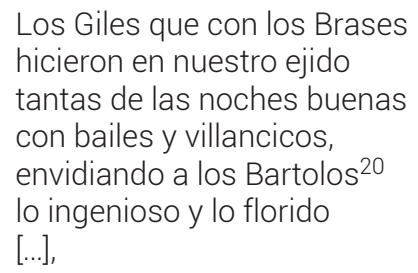

17. Es curiosa la insistencia en el cansancio de estos pastores. Aquí es Sancho Panza quien les sustituye, pero en otros villancicos son personajes folklóricos como Perico y Marica, que aluden a dos personajes folklóricos muy viejos y que evocan un tiempo muy lejano: el rey Perico y Mari Castaña (ver Borrego, 2019, pp. 89-90). Son ellos quienes reemplazan a Antón y Pascuala. Esta alusión metaliteraria refuerza el desfase de la presencia de pastores en estos textos ya bien avanzado el siglo: «Perico y Marica, que antes / eran Antón y Pascuala, / dentro de Belén se encuentran / como en todas partes se hallan» (DR: N1696, II). 18. A propósito de las seguidillas, es muy ilustrativo el comienzo de un villancico en el que se reniega de las chambergas también por viejas. Los pastores habituales van a ver al Niño y van comentando sobre cada figura del Portal y sobre la propia chamberga y el modo de cantarla. Se reconoce que el tono «es viejo», como los zagales que lo cantan y bailan: «Cantemos acordes / todos a compás. / Vaya una chamberga. / ¡Diga! / Pues notad / que este tono es viejo» (DR: N1684, III).

19. En un interesante duelo verbal entre un poeta de comedias y otro de villancicos se hace alusión a temas y personajes ya viejos: «[POETA DE COMEDIAS] También traigo comedias / yo, donde solo / se ha quedado en ayunas / el auditorio. / [POETA DE VILLANCICOS] ¿Qué fuera de los Pascuales, / los Giles y las pastoras, / si un poeta de obra pía / no fundara sus memorias?» (DR: N1688, VII).

20. Contamos con un villancico dedicado enteramente a los «donaires de Bartolo», que comienza así: «Afuera, afuera, que salen / con zamarra y con pellico, / puestos en un villancico / de Bartolo los donaires. / ¡Afuera, afuera, que salen! / Di, Bartolo, algo de gusto / a este natal admirable. / Digo que el Niño que ven / es más hombre que su padre» (DR: N1696, VII). Las coplas se articulan en torno al diálogo entre Bartolo, que va soltando sus donaires, y un coro. 


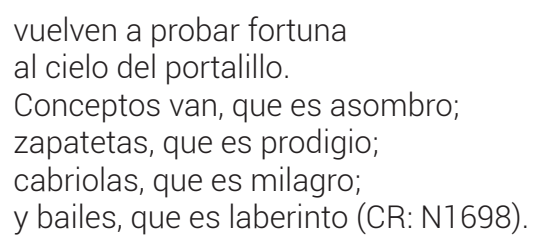

Pero ampliemos el elenco pastoril en sus personajes concretos: en nuestros villancicos, ellos son Domingo, Bato, Pascual, Bartolo, Toribio, Perote, Mingo, Llorente, Bras, Gil, Miguel y Antón; ellas: Pascuala, Menga, Inés, Gila y Gileta, nombres similares a los de muchos de los pastores antiguos de Encina ${ }^{21}$. Lo curioso es que la presencia de estos zagales concretos se hace casi fija e inherente al género, como se refleja en un villancico de la Capilla Real de 1665, donde además se alude a la «especialidad» de cada pastor ${ }^{22}$, que se explotaba humorísticamente en otros villancicos de tono popular. Sin embargo, hay que hacer notar que precisamente esta pieza, aunque los nombres de los zagales evocan personajes cómicos, se reviste de un tono lírico y muy cercano a las piezas cultas que comentaré en último término:

1. Entró, con grande opinión, maese Bras al portalico y repartió un villancico de donaire y devoción. Luego sacó del zurrón las letras, con mucho aliño, al nacimiento del Niño en estilo pastoril. Toquen, toquen el tamboril. 2. Cantó una jácara Bras, muy hosco y muy agobiado, celebrando un sol helado más valiente que el que más, y al bullicioso compás de la airosa guitarrilla le bailó, que es maravilla, un pasacalle gentil. Toquen, toquen el tamboril.
5. Cantó Gil a la vihuela un villancico muy grave $y$, con estilo suave, celebró al sol que se hiela. Lo travieso de la suela tanta gravedad no admite y así se buscó el desquite en las cabriolas Gil. Toquen, toquen el tamboril. 6. Ver a Pascual admiré, que un negrillo de manera cantó, como si viniera de Angola o Santo Tomé. Dijo acaso «cucambé», y díjolo en tan buen hora que lo ha bailado hasta ahora en Belén y en el redil. Toquen, toquen el tamboril.

21. Los pastores de Encina son: Pelayo, Domingo, Juan, Juanillo, Pascual, Pascualillo, Bartolo, Mingo, Minguillo, Lloriente, Beneito, Bras, Pedruelo, Gil, Juan, Miguelejo, Rodrigacho, Antón, Piernicurto, Johanparamás, Cristino, Justino, Fileno, Zambardo y Cardonio. Las pastoras: Bartolilla, Bartola, Pascuala, Menga y Febea. Para la obra de Encina, sigo la edición de Pérez Priego, 1996 y me atengo a los doce villancicos pastoriles (pp. 733-768) y a las denominadas «representaciones» (pp. 769-962). 22. En otros villancicos se alude a esa «especialidad»: «Caminen los zagales, / ninguno se detenga. / Antón lleve la gaita, / Bartol las castañetas» (CR: N1661, VII). Nótese cómo en sendos villancicos se alude a la procedencia portuguesa de Antón. 
3. A o sol, que fica deitado, cantó un portugués Antón, con magoas do corazón, saudades de namorado. $Y$ después que hubo cantado, embrazando las sonajas, a bailar se hizo rajas y quedó como un brasil. Toquen, toquen el tamboril.

4. Domingo llevó al portal un villancico gallego, y a la gaita bailó luego que tocaba Antón Pascual. Con propiedad, el zagal lo cantó y bailó tan bien como si fuera Belén a las orillas del Sil. Toquen, toquen el tamboril.
7. A la rosa más divina que vio el mayo en su vergel, cantó un morisco Miguel, con propiedad peregrina. Y como el papel se inclina a danzas moriscas más, bailó una zambra al compás de un africano añafil. Toquen, toquen el tamboril. 8. Al son de claro arrebol y a su madre, hermosa y pura, cantó, con grande mesura, un villancico Bartol.

$Y$ tras el remifasol repicó de linda gana la floreta cortesana, la zapateta civil. Toquen, toquen el tamboril (CR: N1660, II).

Lejos están estos versos del pastor tosco y glotón o de las figuras entremesiles de bobos y simples. Es cierto que existe un parentesco entre los géneros del teatro breve y los villancicos, hasta el punto de que existen «villancicos de baile», «de jácara» e incluso de «mojiganga», tema bien estudiado por Llergo y Di Pinto23, pero, salvo algún caso concreto en la modalidad «baile», no fueron estos pastores protagonistas de esas piezas. Es más, creo que la parodia de su rudeza está matizada, se enfoca con suavidad, de modo que lo que podría ser caricatura de un defecto, por ejemplo, o de un vicio censurable, se convierte en algo simplemente risible en el entorno navideño. Es el caso de un pastor bruto, o de dos zagales, uno tuerto y otro cojo 24 :

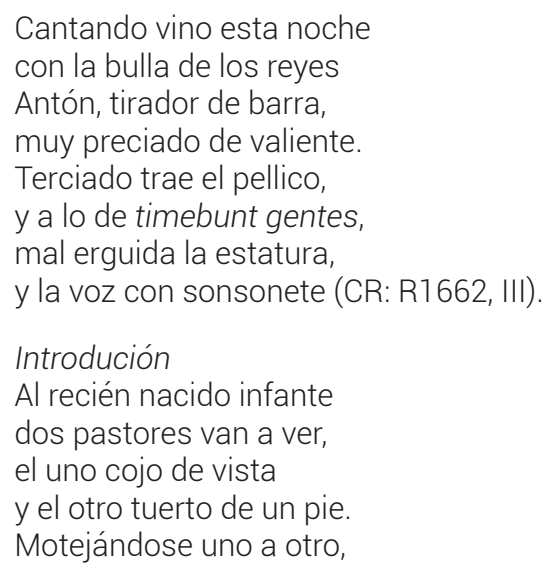

23. Ver Llergo, 2017, pp. 279-323, 402-420 y Di Pinto, 2018.

24. Respecto al primer texto, se lleva a escena una especie de miles gloriosus, y en el segundo se reconoce a dos personajes de la tradición cómica, la pareja del tuerto y el cojo, presente ya en el Libro de Buen Amor. 


$\begin{array}{ll} & \begin{array}{l}\text { caminan hacia Belén; } \\ \text { óiganlos, porque el coloquio } \\ \text { dará a la noche placer. }\end{array} \\ & \text { Diálogo [Estribillo] } \\ & \text { Bartolo, ivas al portal? } \\ \text { TUERTO } & \text { No, Pascual. } \\ \text { COJO } & \text { Pues, ipor qué? } \\ \text { TUERTO } & \text { Porque no tengo más de un pie. } \\ \text { COJO } & \text { ¿Eso es cierto? } \\ \text { TUERTO } & \text { Tan verdad como ser tuerto. } \\ \text { COJO } & \text { Eso no me causa enojos, } \\ \text { TUERTO } & \text { que antes me pienso reír. } \\ & \text { Ś́, que no podrás decir } \\ \text { COJO } & \text { lo sientes sobre tus ojos. } \\ & \text { Nada será que digas } \\ \text { TUERTO } & \text { nuevo en la fiesta } \\ & \text { que los dichos de un cojo } \\ & \text { traen muleta (CR: N1676, III). }\end{array}$

Los diálogos entremesiles en los que dos personajes antagónicos discuten o presentan visiones contrapuestas sí están presentes en algunos villancicos de pastores: es el caso de Gil, más idealista, y Bartolo, más práctico y mundano ${ }^{25}$; o de la discusión entre dos pastoras, una lista y una boba:

$\begin{array}{ll}\text { [GIL] } & \text { Oye y verás, Bartolillo, } \\ & \text { pues nos oye nuestro rey, } \\ & \text { los presentes que le dan } \\ & \text { los que llegan a ofrecer. } \\ & \text { Veré una maravilla, } \\ & \text { según me cuentas, } \\ & \text { pues ya no dan aquellos } \\ & \text { que hacen ofertas (CR: R1666, I). } \\ & \text { Introducción } \\ & \text { Una pastora muy simple } \\ & \text { y una zagala discreta, } \\ & \text { el más sazonado plato } \\ & \text { dieron en la Noche Buena. } \\ \text { Celebrar quieren al rey } \\ \text { cada una con su tema. } \\ \text { [...] }\end{array}$

25. En otros villancicos aparece Bartolo como pastor idealista y culto, y otro zagal, aquí Perote, como más material y realista: «[BARTOLO] ¿Qué cosas son éstas, / amigo Perote? / ¿A Dios con trabajo / y contento el hombre? / [PEROTE] Si quieres, Bartolo, / tener buena noche, / cuidados ajenos / no te maten, oyes. / [BARTOLO] ¿No quieres que sienta? / ¿Acaso soy bronce? / ¿Ver entre dos brutos / al más rico pobre? / [PEROTE] Sobre tu rebaño / pon las atenciones, / pues ves que los otros / tienen sus pastores. / [BARTOLO] A cuanto te digo, / muchacho, respondes, / no te hagas perito, / pues eres Perote. / [PEROTE] Bien dices, prosigue / tus admiraciones, / que los zagalejos / no somos dotores» (CR: R1687, II). 


\begin{tabular}{|c|c|}
\hline & Coplas \\
\hline DISCRETA & $\begin{array}{l}\text { Cuando Dios Niño se duerme } \\
\text { es cuando más se desvela, } \\
\text { que aunque sosiegan sus ojos } \\
\text { su corazón no sosiega. }\end{array}$ \\
\hline SIMPLE & $\begin{array}{l}\text { Hablar claro es lo que importa } \\
\text { si de discreta se precia, } \\
\text { porque si no es entendida, } \\
\text { ¿cómo quiere ser discreta? }\end{array}$ \\
\hline DISCRETA & $\begin{array}{l}\text { Desde que Adán, como bruto, } \\
\text { rompió a un precepto la rienda, } \\
\text { con las pajas del pesebre } \\
\text { le llama Dios porque vuelva. }\end{array}$ \\
\hline SIMPLE & $\begin{array}{l}\text { Dios gusta también de simples, } \\
\text { pues, siendo la suma ciencia, } \\
\text { no naciera entre animales } \\
\text { si no gustara de bestias (CR: N1674, II) }\end{array}$ \\
\hline
\end{tabular}

Pero las disputas entremesiles por antonomasia son las matrimoniales, y también están presentes en los villancicos, como he anticipado con la pareja pastoril más famosa, Bras y Menga. La lucha de sexos y los problemas conyugales a causa de la supuesta condición irreconciliable de hombres y mujeres aparece en otros dúos, como Pascual y Gila. En un tono festivo, él la acusa de entrometida, correndona, necia y pecadora como Eva, mientras que ella tan solo le insta a que deje las chanzas y se defiende de las acusaciones:

$\begin{array}{ll}\text { GILA } & \begin{array}{l}\text { Vamos, Pascual, a Belén, } \\ \text { porque hay mucho que admirar. } \\ \text { ¡Por cuánto no te moviera, } \\ \text { mujer, la curiosidad! }\end{array} \\ \text { GILA } & \begin{array}{l}\text { A los ángeles voces } \\ \text { siguiendo los pastores van. } \\ \text { Yo creo tu devoción } \\ \text { solo por irte a pasear. }\end{array} \\ \text { PASCUAL } & \begin{array}{l}\text { Aguija, y deja las chanzas } \\ \text { que no es tiempo de ellas ya. }\end{array} \\ \text { PASCUAL } & \begin{array}{l}\text { Aún temo entre los milagros } \\ \text { me aciertes a aconsejar. }\end{array} \\ \text { GILA } & \begin{array}{l}\text { Pues ¿qué?, ihas errado por mí, } \\ \text { toda tu vida, Pascual? }\end{array} \\ \text { PASCUAL } & \text { Es que esta noche me acuerda } \\ \text { lo que por Eva hizo Adán. } \\ \text { GILA } & \text { Ella no erró por malicia; } \\ & \text { Adán sí, que supo más (CR: R1671, VI). }\end{array}$

Sin embargo, contamos con un texto en el que entre Bras y Menga ya hay palabras mayores, pues ella pide ante el Belén amparo para ser librada del maltrato físico al que la somete su marido. Aunque en un contexto contemporáneo nos permitiríamos dudar del tono festivo del villancico, hay que apuntar que el memorial 
burlesco era un subgénero típico de la poesía festiva y, que de hecho, aquí el autor lo califica de «gracioso papel» ${ }^{26}$ :

\author{
Introducción \\ 1. Los reyes a los zagales \\ dieron audiencia en Belén \\ y lo que siempre es afán \\ hoy fue grato placer. \\ 2. Sin guardar la licencia, \\ Menga y Bras dieron al Rey \\ su memorial cada uno \\ que fue gracioso papel. \\ Coplas
MEngA Señora, Bras me maltrata,
y llevar no puedo ya,
en hombre tan miserable,
mano tan liberal.
¡Ay, déjenmela hablar!
BRAS No puedo negar que a Menga,
sobre que me tenga ley,
la asenté los mandamientos ${ }^{27}$
como hizo Dios a Moisés.
¡Ay, déjenmele ver
a mi Niño, mi dueño y mi rey!
MENGA ¡Ay, déjenmela hablar
a la aurora del sol alemán 28 !
Bras me pega a todas horas
y su mano criminal
es de reloj de campana,
que señala lo que da.
¡Ay, déjenmela hablar! (CR: R1675, VI).

En ocasiones, la discusión matrimonial la provoca algo tan absurdo como si este es el día de Corpus o es la noche de Navidad. Fuera de la perogrullada, lo que tiene interés es que la confusión viene inducida porque en ambas ocasiones se cantaban villancicos, por lo que estamos de nuevo ante una alusión metaliteraria:

26. Si los lectores del siglo XVII encontraban graciosos los palos que recibe don Quijote, probablemente también encontrarían graciosos los que recibe Menga, pues se insertan en un entorno burlesco.

27. Se entiende mandamiento como «precepto de la ley de Dios», pero también, «en estilo bajo, llaman así los dedos de las manos, cuando se usa de ellos o para comer o para castigar» (Aut.). En los siguientes versos, Menga habla de la «mano criminal» de Bras y directamente de que le pega «a todas horas».

28. En los villancicos se identificaba a la reina del momento con la Virgen: la «aurora del sol alemán» era Mariana de Austria, reina regente hasta la mayoría de edad de Carlos II, que llegaría en noviembre del mismo año de la ejecución de esta pieza, 1675. 


\begin{tabular}{|c|c|}
\hline & $\begin{array}{l}\text { Estribillo } \\
\quad \text { Gila y Antón, } \\
\text { ante el rey, una cuestión } \\
\text { forman de gracioso chiste, } \\
\text { y su argumento consiste } \\
\text { probar con simplicidad } \\
\text { que es día de Corpus Christi } \\
\text { la noche de Navidad. }\end{array}$ \\
\hline [ANTÓN] & No dices bien. \\
\hline [GILETA] & No digo mal. \\
\hline [ANTÓN] & $\begin{array}{l}\text { Gileta, aquesta es, no hay duda, } \\
\text { la noche de Navidad. }\end{array}$ \\
\hline [GILETA] & $\begin{array}{l}\text { Antón, es día del Corpus, } \\
\text { y no hay que dudar. }\end{array}$ \\
\hline [ANTÓN] & ¿Hay semejante mayor? \\
\hline [GILETA] & $\begin{array}{l}\text { ¿Hay en el mundo tal? } \\
\text { No tal, sí tal. }\end{array}$ \\
\hline COROS & $\begin{array}{l}\text { Oír y callar, } \\
\text { que esta noche festiva la hace } \\
\text { hermosa la variedad (CR: N1699, II }\end{array}$ \\
\hline
\end{tabular}

Como es sabido, otra estructura típica de entremeses era la de «desfile de personajes», aquí transformado en una mascarada de pastores "con su alcalde y regidor» (típicos personajes «bobos» del teatro breve), acompañada de canto y baile. Recordemos que las mascaradas era divertimento también nobiliario, lo que nos retrotrae a esos pastores encinianos que actuaban para los egregios públicos palaciegos:

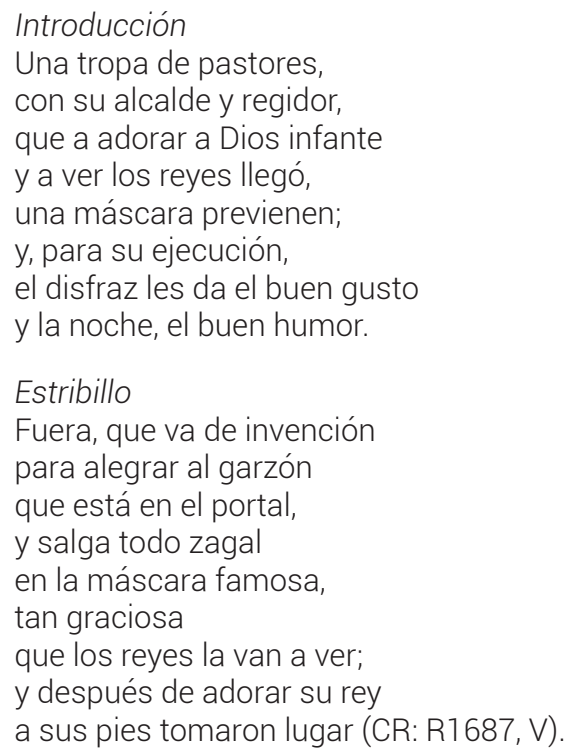


La comicidad está presente en el grotesco desfile de pastores ridículos (Gil Perales, Bras, Antón, Toribio y Llorente) a modo de mascarada, y se procede a la parodia de los atuendos propios de estos divertimentos: uno «traía su toca puesta / y su cabello rizado, / y por sayo ajironado / del suyo llevó un jirón»; otro «Con la túnica enfaldada / iba Antón, haciendo piernas, / por estribos, dos linternas, / por capacete, un melón». No falta tampoco un tipo de comicidad muy entremesil: el ridículo escénico, pues las parejas corren mientras se tiran de las orejas: «Corrieron sendas parejas, / Bras y Gil, sin desmandarse, / y para más ajustarse, / se asieron de las orejas. / Las lanzas eran dos rejas / que quitaron de un terrado, / y el color aceitunado / que tira a melocotón». Los términos, aquí tratados cómicamente, son propios de estas diversiones nobiliarias: lanzas, colores de las divisas, parejas, estribos, justas, etc. Pero hay otras mascaradas muy alejadas de ese remedo del ocio nobiliario, en las que incluso se alude a «las vejeces» de esta modalidad festiva. Adviértanse las notas costumbristas y lo grotesco de personajes y situaciones:

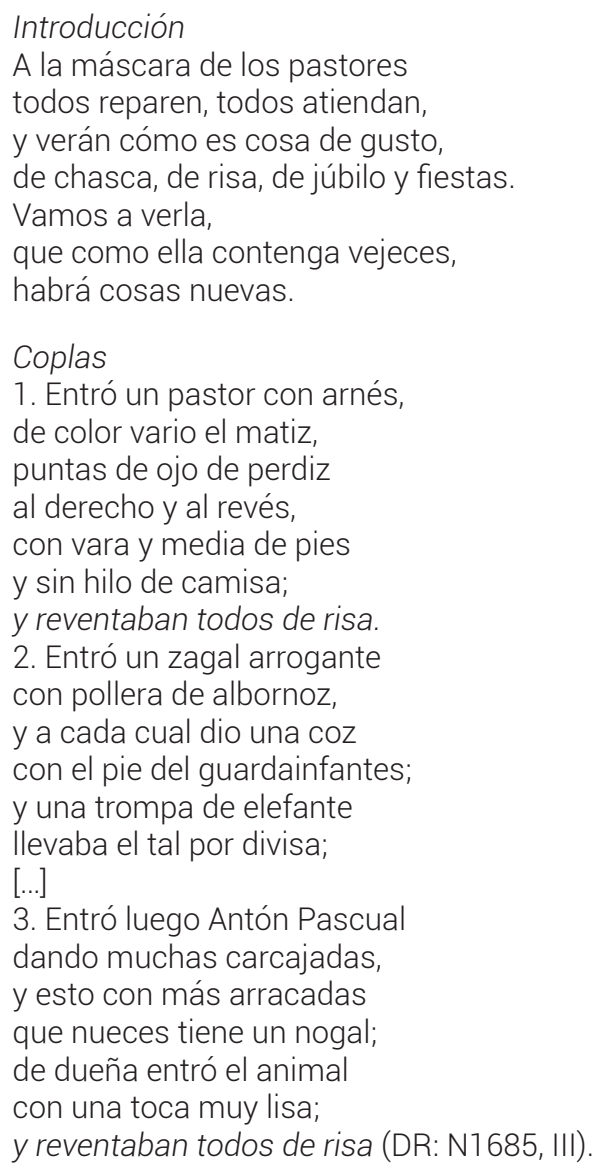


Fuera de mascaradas, no faltan en estas piezas otros desfiles burlescos, desplegados en la «Corte de Belén», donde aparecen figuras como la pastora Inés, de gran desparpajo, o el pastor bobo que se identifica a sí mismo con una bestia:

\author{
A un ciego de nacimiento \\ dijo la pastora Inés: \\ "oye usted, yo me contento \\ solo con que mire usted» (DR: N1682, II). \\ Mirando al buey y la mula \\ dijo un pastor inocente \\ que eran bellos animales, \\ quitando lo presente (DR: N1680, III)
}

Otros contextos relacionados con el entremés, pero a su vez emparentados con géneros híbridos como los bailes, nos presentan al pastor en una de sus caracterizaciones más antiguas, cantando y bailando al Niño Jesús. Apenas hay acción ni trama, pero el elemento coreográfico y el musical, unido a la fuerza de las onomatopeyas, son determinantes ${ }^{29}$ :

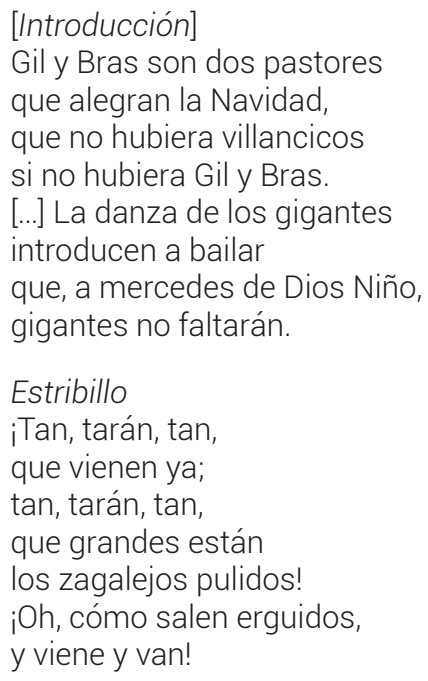

29. Villancicos con pastores bailando hay muchos. Baste con indicar el ejecutado en segundo lugar en los maitines de Navidad de 1687 en el Convento de la Encarnación, en el que se ejecuta una «danza de pastores» y el quinto de Reyes de 1690 del mismo cenobio, donde unas zagalas exponen diferentes tipos de danzas. Bailes de zagalas en solitario están presentes, también en la Encarnación, en la Navidad de 1691 (IV), 1693 (III) y 1694 (II). 
¡Ay, ay, cómo bailan,

ay, cómo brincan,

ay, cómo saltan!30 (CR: N1657, II).

Estos zagales danzarines no solo cantan y bailan en un entorno pastoril, sino que, en el contexto de un villancico en el que cada uno inventa un baile, hay uno que se atreve a ejecutar uno de matachines, un tipo de danza muy específica del teatro cómico breve, venida de Francia y que deriva de los antiguos mimos y de la escuela de la Commedia dell'arte. No era un simple baile, sino un espectáculo casi teatral, pues los danzantes se disfrazaban de guerreros $y$, al son de una flauta, se golpeaban con palos entre estruendos y saltos ${ }^{31}$ :

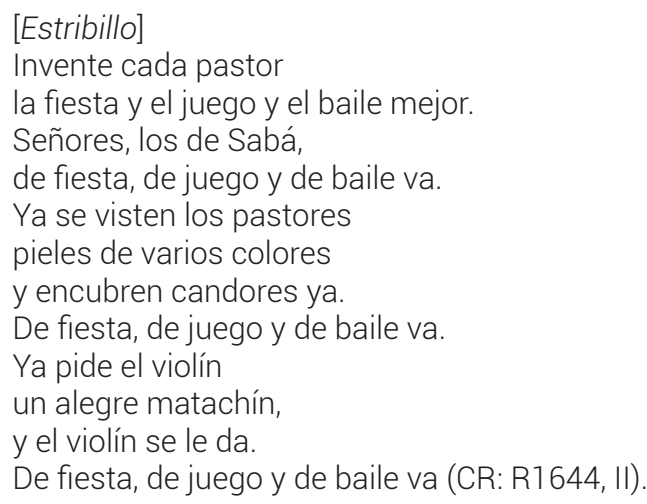

El hibridismo del pastor cómico con el emisor de un determinado discurso lírico está quizá levemente presente desde los villancicos de Góngora, como es el caso del destinado a la Navidad que se cantó en la catedral de Córdoba en 1615: junto a las consabidas expresiones gongorinas se percibe ya una cierta presencia del componente teatral en el diálogo entre dos pastores que sirven de presentadores de otros personajes que llegan al portal, aunque hay que reconocer que el villancico entraría dentro de los «líricos», así como el tipo de pastor:

\begin{tabular}{|c|c|}
\hline GIL & $\begin{array}{l}\text { No sólo el campo nevado } \\
\text { yerba producir se atreve } \\
\text { a mi ganado, } \\
\text { pero aun es fiel la nieve } \\
\text { a las flores que da el prado }\end{array}$ \\
\hline
\end{tabular}

30. Llergo afirma que los villancicos de baile están asociados al pastor, al gallego y al negro (ver Llergo, 2017, p. 403). Por otra parte, en estos versos se apunta a que eran típicos los «bailes de pastores»: «De pastores un baile / se hace muy bueno, / y porque el entremés no haga falta / se hace el del negro» (CR: N1665, VI).

31. Parece que el motivo de los pastores vestidos de matachines debido al cansancio de las danzas de pastores y sus instrumentos llegó hasta final de siglo: «Cansados ya los panderos, / sonaja, flauta y tambor / de hacerles bailes al Niño, / nueva danza es la de hoy. / Hacer unos matachines / ordenaron Bras y Antón / y, vestidos de botarga, / así empezaron los dos» (DR: N1692, VIII). 


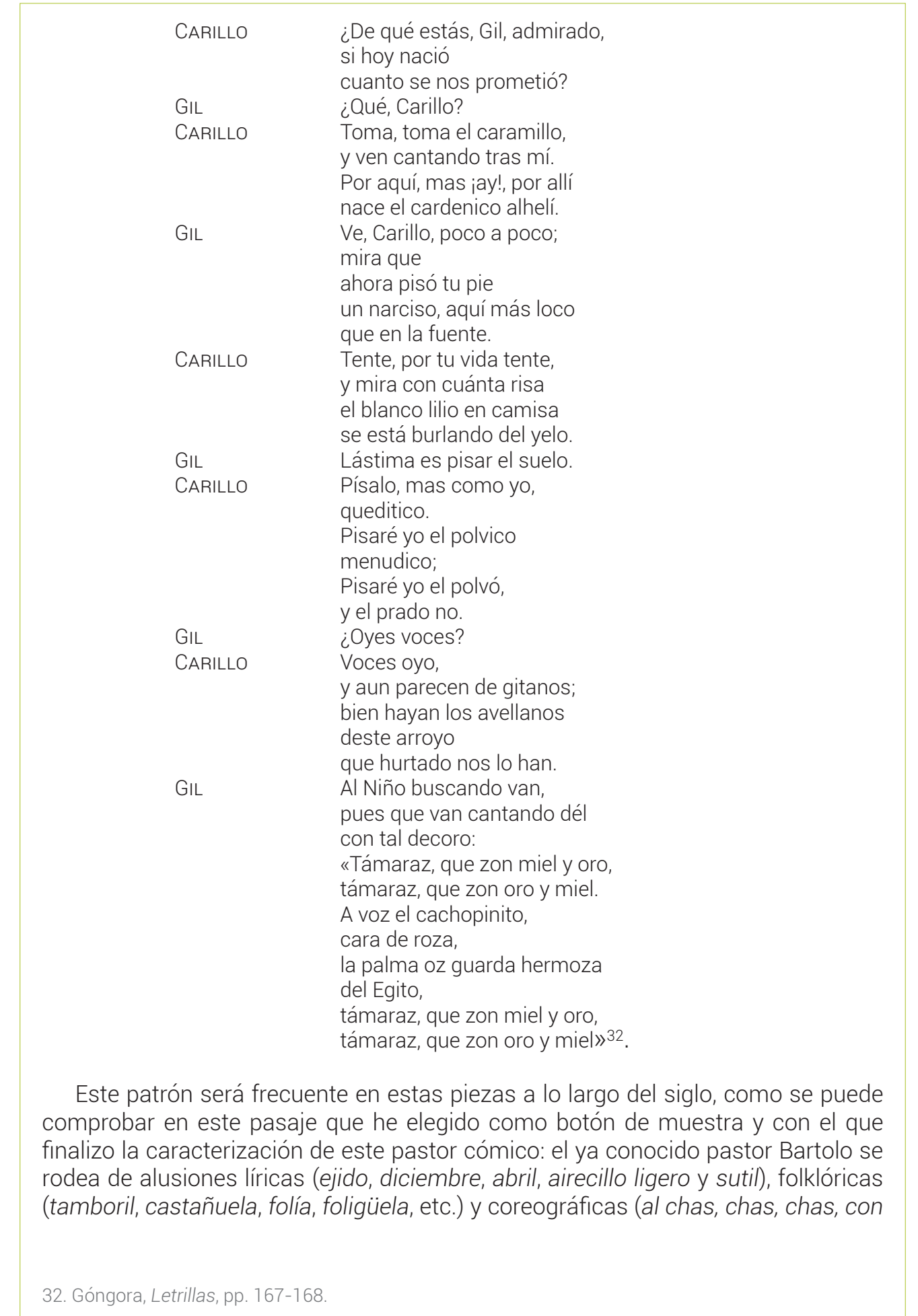


la castañuela, y al tapalatán [...] Vaya de bailes [...], mostrando una vez más la inspiración híbrida de la figura, pues aquí se aleja de su habitual condición cómica acercándose al modelo de pastor lírico:

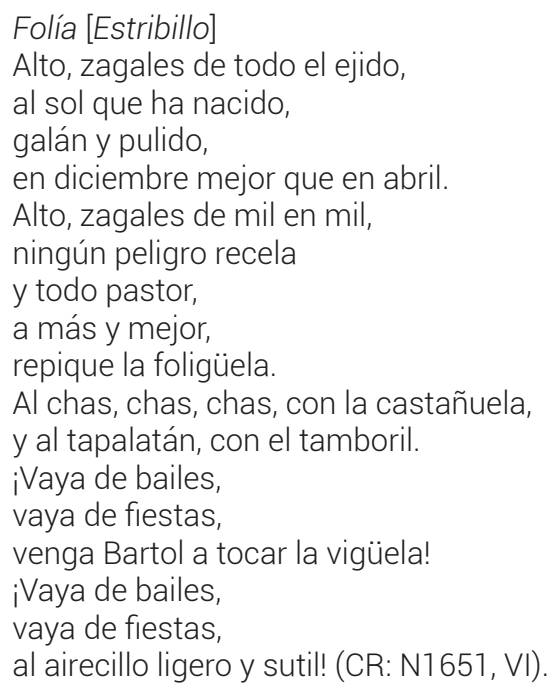

Entramos ahora a dilucidar las funciones del segundo tipo de pastor: el sencillo de raíz evangélica, alejado de cualquier viso de caricatura o parodia. Lo primero que hay que apuntar es su funcionalidad y su abundante presencia, que se diversifica 1) como receptor de una llamada para adorar al Niño, seguir la estrella, llevar presentes, etc.; 2) como sujeto que emite discursos de tono popular en primera persona en esta misma línea y, por último, 3) formando parte de una Introducción, sección inicial del villancico que presentaba el tema del mismo, generalmente describiendo actuaciones de los pastores en tercera persona, siempre en el entorno del Belén. Una de las claves de este personaje se da en un villancico donde se identifica el discurso de estos pastores con un «idioma sencillo» pero que no elude «elegancias»:

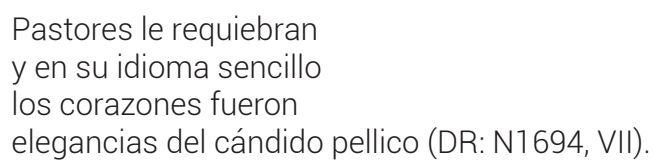

Son numerosos los textos en los que figuran uno o varios pastores o pastoras como receptores de una llamada para adorar, al modo que hicieron los ángeles exhortando a los pastores a adorar al Niño (ver Lucas, 2, 10-12) ${ }^{33}$. Suele introducirse el texto con un vocativo seguido de la alusión al Niño Jesús:

33. En ocasiones figura directamente el texto evangélico: «Albricias, pastores, / albricias, zagales, / que exclaman, que suenan, / que entonan, que aplauden / "Gloria en las alturas / y paz en los valles» (CR: N1684, VII). 


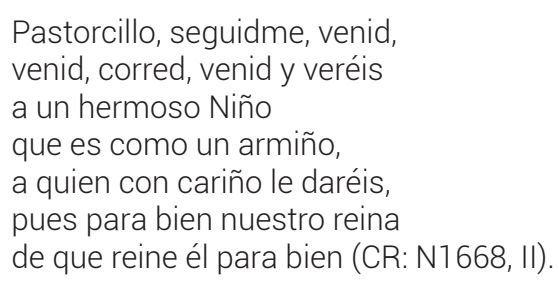

Este recurso se emplea específicamente en la modalidad del «Villancico de adoración», que solía finalizar la celebración de los maitines navideños en el Monasterio de las Descalzas Reales. La adoración al Niño implicaba a los pastores sencillos y toda la pieza giraba en torno a ellos:

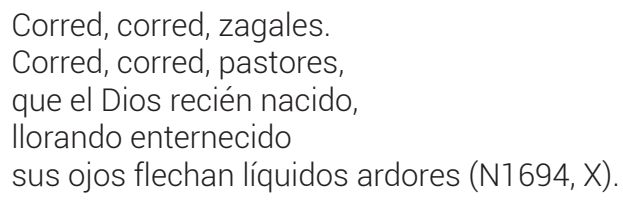

No es infrecuente que tras esta llamada a los pastores se introduzcan pasajes de tipo lírico, más propios del pastor culto que trataré en el último apartado. Una vez más el villancico se resiste a mantener un único tono o estilo en sus versos, como es este caso:

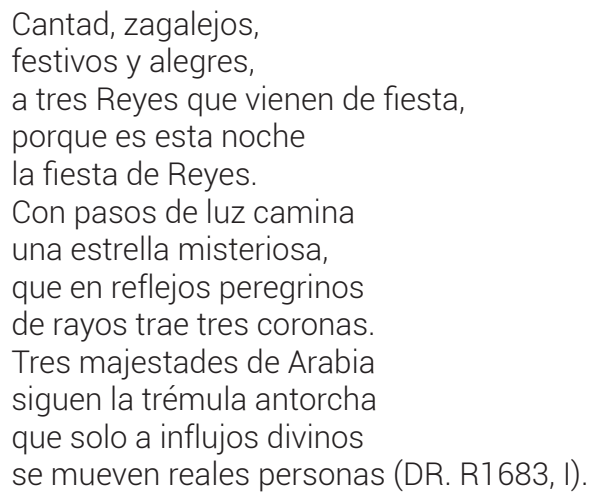

En cuanto al sujeto pastoril que emite tiernos discursos para el Niño, la Navidad o los Reyes, hay que precisar que los límites entre el tono popular y el culto en ocasiones no son tan claros, como ocurre en este precioso diálogo, en el que una zagala enamorada responde a las preguntas de otra pastora:

PASTORA ¿Dónde llevas tus lindas ovejas tan de mañana, pulida zagala?

ZAGALA Tengo un cuidadillo que me roba el alma, pastora agraciada. 


\begin{tabular}{|c|c|}
\hline PASTORA & $\begin{array}{l}\text { Mira que aun la noche } \\
\text { sus sombras dilata. }\end{array}$ \\
\hline ZAGALA & $\begin{array}{l}\text { No, que he visto al Sol } \\
\text { en brazos del Alba. }\end{array}$ \\
\hline PASTORA & No puede ser, pastora. \\
\hline ZAGALA & Sí puede ser, zagala. \\
\hline PASTORA & $\begin{array}{l}\text { Parece que sueñas } \\
\text { de estar desvelada. }\end{array}$ \\
\hline ZAGALA & $\begin{array}{l}\text { Tengo un cuidadillo } \\
\text { que me roba el alma (DR: N1690, III) }\end{array}$ \\
\hline
\end{tabular}

A continuación, es esa «simple pastorcilla» la misma que canta al Niño: «Que tiritando llego, / Niño mío, a tu dulce fuego, / que tiritando vine / y ya el alma se me derrite, / ¡ay vida mía!». No puedo menos que advertir una mezcla del tono popular con el culto, pero dejo al criterio del curioso lector discernir sobre el mayor o menor peso de cada uno.

Otra modalidad escénica propia de este personaje es aquella en la que un pastor cuenta a otro la escena de la Navidad, sin más, evocando el Evangelio y haciéndolo como si tuviera interlocutores, aunque en realidad se trata de un monólogo encubierto sobre el prodigio del Nacimiento de Jesús:

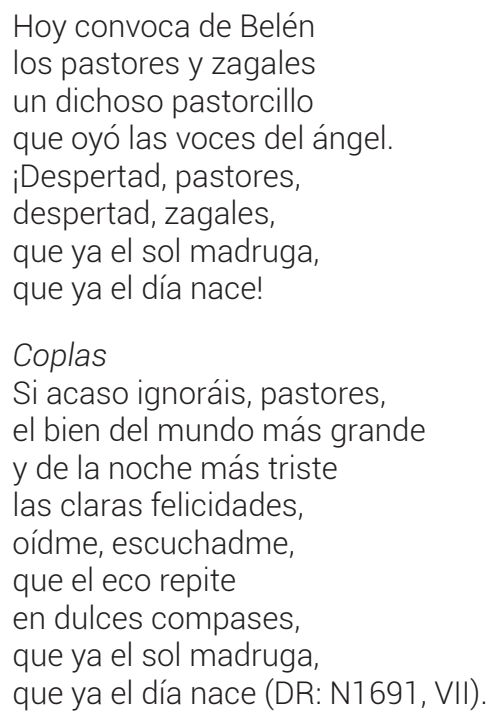

Otras veces, el relato del pastor se ve precedido de un diálogo de tipo teatral con otros zagales, a los que atropella con su alegría por haber encontrado al Niño. De nuevo la frontera entre lo lírico y lo teatral es difusa: 
1. Loco estoy de contento, zagales, tenedme, dejadme.

2. ¿Y cuál es la causa?

1. Oídme, escuchadme. íbame yo con mis blancas ovejas discurriendo por el valle,

y vi... yo no sé lo que vi, pastores, tenedme, dejadme.

3. ¿Qué viste zagal?

1. Oídme, escuchadme.

Vi (como hay Dios) de un pesebre en las pajas

al amor desnudito al aire:

un Niño de perlas, un sol de jazmines,

tenedme, dejadme,

loco estoy de contento, zagales (E: N1687, VIII).

Numerosos son también los villancicos en cuya introducción se menciona a los pastores en el entorno de la escena del Belén, haciéndose preguntas sobre el misterio, procurando ropa al Niño o jugando para divertirle. Me permito seleccionar varios pasajes en torno a estos motivos, donde los pastores no intervienen en los diálogos ni ostentan rasgos cómicos; simplemente forman parte del paisaje de la Navidad de una manera más original y creativa que la mera adoración, pero siempre buscando divertir al Niño, consolarle, abrigarle, etc.:

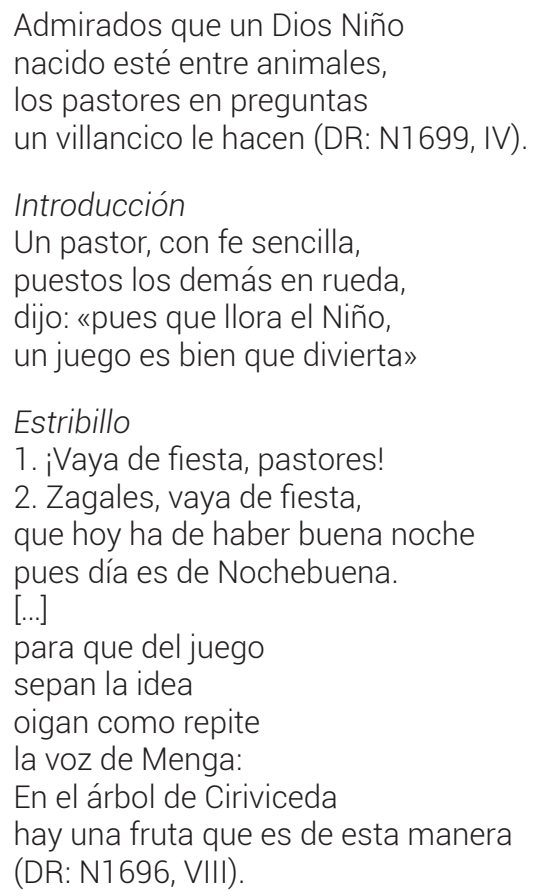




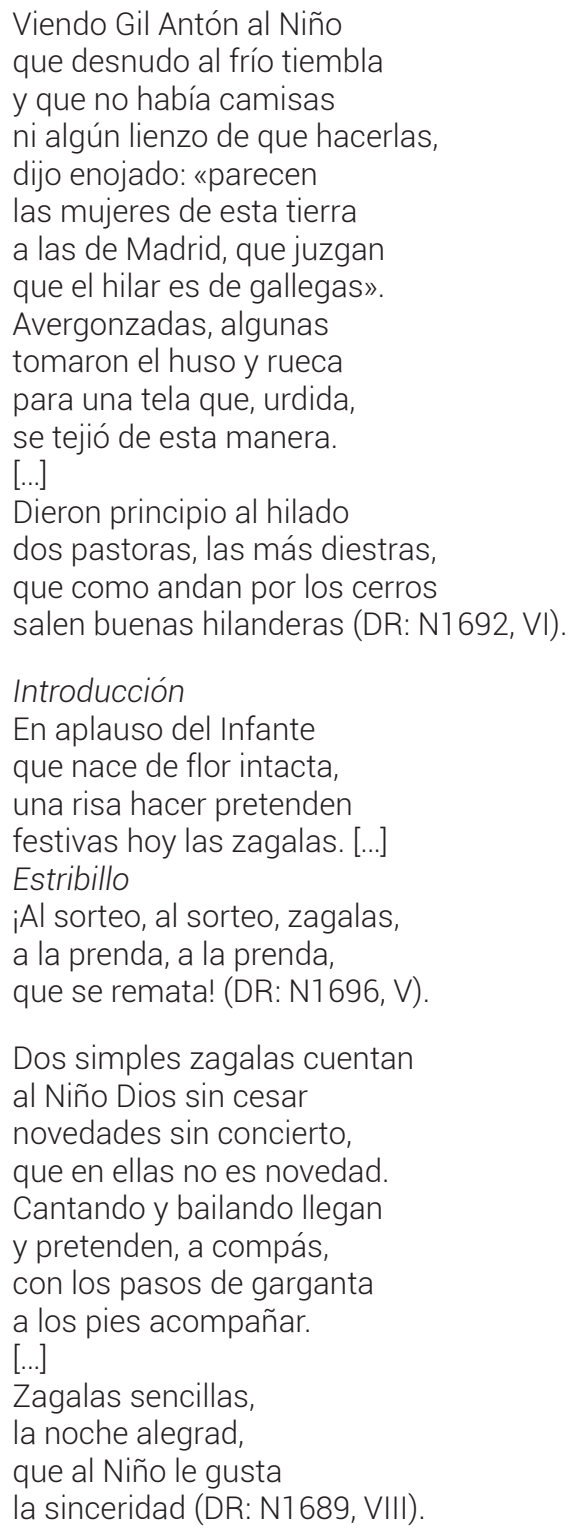

El tercer tipo de zagal villanciqueril es el pastor culto heredero de la tradición virgiliana e italiana más próxima, que bien podría poblar las páginas de géneros pastoriles de éxito en los siglos XVI y XVII. En realidad, aunque el contexto fuera navideño, el discurso de este tipo de pastores sigue la línea de los recursos cancioneriles en textos de temática amorosa, eso sí, vueltos a lo divino. Pero no es él siempre el que habla, pues en muchas ocasiones aparece como interlocutor de quizá otro pastor culto: 
[Estribillo]

¡Oh, qué bueno, pastores, qué bueno

ver en lágrimas tan bellas

las más brillantes centellas

ceñir un portal de estrellas

y de aljófares el heno!

¡Oh, qué bueno

que del seno de María

nacen la gloria y el día,

y que también de alegría

luces respira otro seno!

¡Oh, qué bueno

que la noche vierte albores,

que el hielo produce amores,

que el dar la nieve en las flores

es lo menos en lo ameno!

Coplas

1. Los aires y los alcores

se coronan de alegrías,

se compiten de armonías,

se bañan de resplandores.

2. Y de ángeles y pastores

se forman cielos segundos,

celebrándolo en dos mundos

los rebaños de Fileno ${ }^{34}$

¡Oh, qué bueno, etc.! (CR: N1641, VI).

1. Pastorcillo curioso, que al valle flor a flor la hermosura registras,

¿dónde caminas?

¡Ay, dichosos campos!

¡Ay, selvas floridas!

¡Ay, no llores!

¡Ay, no penes!

¡Ay, no gimas!

Ocultan los valles

la Flor Peregrina,

un tiempo esperada

y ya poseída. [...]

2. Con amoroso desvelo

busco la Flor Peregrina,

que el mundo no la conoce,

naciendo para su dicha;

y es tan linda 


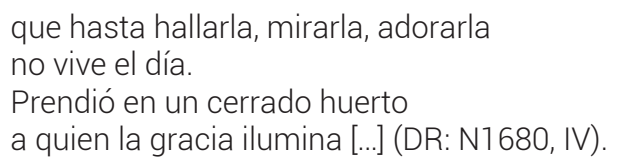

Los pastores cultos reunidos para cantar sus poemas o resolver enigmas tampoco escapan a los versos de estas piezas. En este villancico se invoca a los pastores para que descifren el enigma sobre quién es el Niño Jesús, y la discusión gira en torno a desglosar por qué el Niño es nieve, deidad, flor y gigante (tan solo transcribo el estribillo, el resto es una buena muestra de ejercicio retórico barroco):

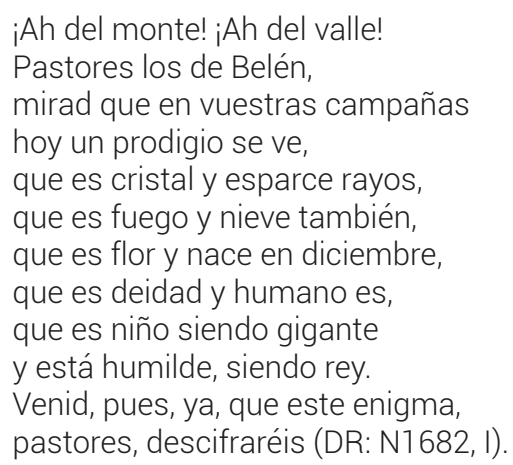

En otros contextos, es el mismo pastor quien canta al Niño, casi siempre presentado por un estribillo o unos versos introductorios. Por cierto, nótese cómo se le bautiza con un nombre de pastor cómico, Gil35, lo que vuelve a acentuar el hibridismo del personaje:

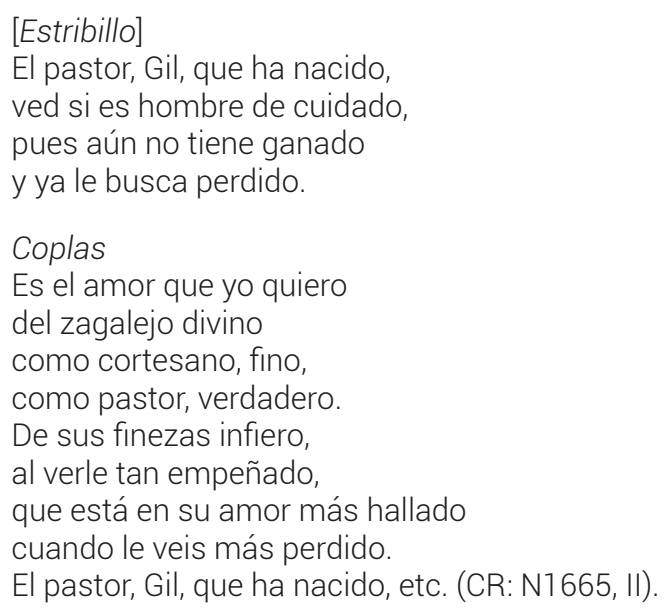

35. Es cierto que Gil es nombre de pastor cómico, pero, ya en Encina, el pastor cómico puede tener también rasgos líricos, que se intensifican en varios autores del XVI, hasta el punto de que personajes con esos nombres, como es el caso de Gil, terminan definiéndose más por su lirismo que por su comicidad. 
De estilo marcadamente culto es este villancico de tono lírico, en el que el pastor emplea conceptos elevados y se dirige a un interlocutor:

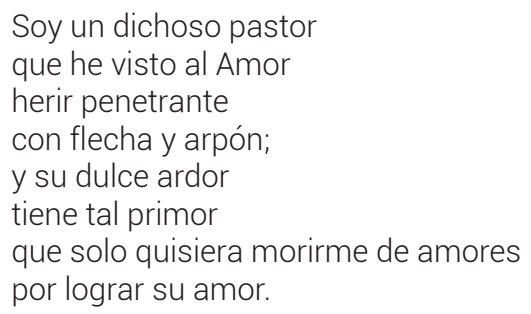

¡Atended a sus señas divinas, moriréis por lograr su favor! ¡Ay, amor, amor! ¡Atended a sus señas divinas, moriréis por lograr su favor!

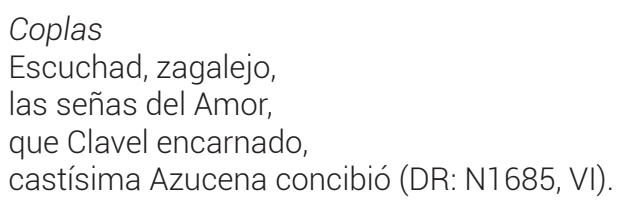

Por el contrario, en otros se mezcla el tono y las alusiones cultas con toques populares, como ya hemos avanzado en otros contextos. La presencia de una zagala con gaita contrasta con las alusiones mitológicas y los motivos típicos de la lírica barroca:

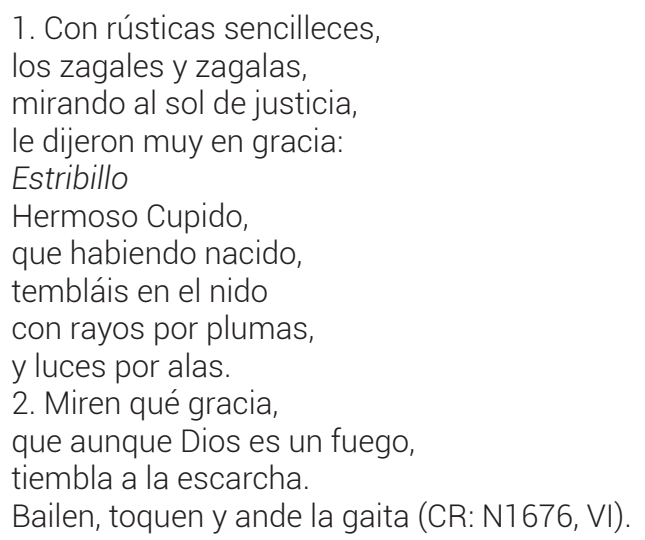

Creo que ha quedado bien demostrada la naturaleza híbrida de estos textos a través de la figura del pastor, solo o acompañado, en pareja o con sus compañeros de oficio, incluso en su versión femenina, la pastora, que a su vez se presenta de similares formas. Se trata del personaje villanciqueril por excelencia, y 
su caracterización, como se ha podido comprobar, es poliédrica y multifuncional. Pero esto no se improvisa, no es fruto de una creación original barroca aislada de su origen. Creo que no se puede negar que la omnipresencia de lo pastoril en los villancicos de Encina es una marca propia que no se perderá en estos villancicos, eso sí, ramificada en una triple vertiente: el pastor rústico-entremesil, el rústicoevangélico y el culto. El puente entre estas formas tempranas tardomedievales 0 prerrenacentistas y el villancico religioso barroco, que eclosiona ya avanzado el XVII (los primeros pliegos son de 1612) es claro, aunque la transición es bastante más incierta. Lo que sí parece cierto es que los pastores entremesiles, que mucha parte de la crítica ha visto como rudos y glotones ya en Encina y Fernández y que se han entendido como el origen o el antecedente del bobo o simple, no funcionaron ni en los pasos de Lope de Rueda ni en los entremeses del XVII, y que el villancico barroco recuperó más bien los pastores sencillos encinianos que aquellos supuestamente zafios y carnavalescos. El hecho de que los pocos pastores protagonistas de géneros propios del teatro cómico breve del XVII estén presentes en formas teatrales como bailes, con muchos puntos en común con el villancico en lo que a hibridismo de lo literario y lo musical se refiere, no deja de llamar la atención, y más que estos pastores canten, bailen y expongan sus celos y problemas amorosos, y no sus bajos instintos. Porque esto mismo ocurre en nuestros villancicos, en el sentido de estar muy alejados de la vis carnavalesca y grosera de un determinado tipo de pastor. Que esto se explique por razones del entorno litúrgico en el que se ejecutaban o que sea cuestión relacionada simplemente con una deliberada elección de orden literario y estético es algo opinable, pero basta un mínimo conocimiento del género para admitir que el villancico, al menos en la dinámica figura del pastor, optó por caminos alejados de los puramente entremesiles y se adentró en el hibridismo entre lo lírico y lo dramático, lo teológico y lo cómico, lo religioso y lo profano, lo popular y lo culto, siempre con esa remota inspiración del pastor enciniano.

\section{BIBLIOGRAFÍA}

Alonso, Álvaro, «Hacia Juan del Encina: amores pastoriles en la poesía de los siglos XIV y XV», en Estudios de literatura medieval. 25 años de la AHLM, ed. Antonia Martínez y Ana Luisa Baquero, Murcia, Universidad de Murcia, 2012, pp. 141-151.

Alonso, Álvaro, «Poesía pastoral entre Encina y Garcilaso», en El texto infinito: tradición y reescritura entre la Edad Media y el Renacimiento, dir. Pedro Cátedra, Salamanca, Universidad de Salamanca / SEMYR, 2014, pp. 257-270.

Asensio, Eugenio, «El Auto dos Quatro Tempos de Gil Vicente», Revista de Filología Española, 33, 1949, pp. 350-375.

Bègue, Alain, «A Literary and Typological Study of the Late $17^{\text {th }}$-century Villancico», en Devotional Music in the Iberian World 1450-1800: The Villancico and Related Genres, ed. Tess Knighton y Álvaro Torrente, Aldershot, Ashgate, 2007, pp. 231-282. 
Bègue, Alain, La poésie espagnole de la fin du XVII siècle: José Pérez de Montoro (1627-1694), membre d'un Parnasse oublié, Sarrebruck, Éditions Universitaires Européennes, 2010, 4 vols.

Bombi, Andrea, «¿Hacia una historia del villancico? Problemas historiográficos de un género musical», en El villancico en la encrucijada. Nuevas perspectivas en torno a un género literario-musical (SS. XV-XIX), ed. Esther Borrego y Javier Marín, Kassel, Reichenberger, 2019, pp. 3-24.

Bombi, Andrea, Carreras, Juan José, y Marín, Miguel Ángel (eds.), Música y cultura urbana en la Edad Moderna, Valencia, Universitat de València, 2005.

Borrego Gutiérrez, Esther, «Los autores de las letras de los villancicos de la CapiIla Real de Madrid (siglo XVII): ¿anonimia como costumbre u ocultamiento de identidades?», Revista de Musicología, 35.2, 2012, pp. 97-129.

Borrego Gutiérrez, Esther, «Un siglo de impresión de pliegos de villancicos. El caso de los Monasterios Reales de la Encarnación y las Descalzas (1649-1752)», El libro de poesía entre Barroco y Neoclasicismo (1651-1750) (volumen monográfico), Criticón, 119, 2013, pp. 127-143.

Borrego Gutiérrez, Esther, «Los caminos de la renovación formal y temática del viIlancico entre 1671 y 1750. El corpus de los Reales Monasterios de las Descalzas y la Encarnación», en Hacia la modernidad. La construcción de un nuevo orden teórico literario entre Barroco y Neoclasicismo, ed. Alain Bègue y Carlos Mata, Vigo, Academia del Hispanismo, 2018, pp. 23-37.

Borrego Gutiérrez, Esther, «Personajes del villancico religioso barroco: hacia una taxonomía», en El villancico en la encrucijada. Nuevas perspectivas en torno a un género literario-musical (SS. XV-XIX), ed. Esther Borrego y Javier Marín, Kassel, Reichenberger, 2019, pp. 58-96.

Borrego Gutiérrez, Esther, y Javier Marín López (eds.), El villancico en la encrucijada. Nuevas perspectivas en torno a un género literario-musical (siglos XV-XIX) (col. Teatro del Siglo de Oro, Estudios de Literatura, 134; Iberian Early Music Studies, 3), Kassel, Reichenberger, 2019.

Bustos Táuler, Álvaro, «"Sonriéndome estoy": Juan del Encina y sus pastores ante la tradición cómica y dramática», en Hacia el gracioso: comicidad en el teatro español del siglo XVI, ed. José María Díez Borque, Álvaro Bustos y Elena Di Pinto, Madrid, Visor, 2014, pp. 15-48.

Caballero Fernández-Rufete, Carmelo, Al sacro esplendor. Villancicos barrocos de la Catedral de Valladolid, Valladolid, Glares Gestión Cultural, 2004.

Di Pinto, Elena, «Villancicos de jácara en un entorno conventual», Edad de Oro, 37 , 2018, pp. 168-183.

Encina, Juan del, Obra completa, ed. Miguel Ángel Pérez Priego, Madrid, Fundación José Antonio de Castro, 1996.

Góngora, Luis de, Letrillas, ed. Robert Jammes, Madrid, Castalia, 1980. 
Knighton, Tess, y Torrente, Álvaro (eds.), Devotional Music in the Iberian World: The Villancico and Related Genres, Aldershot, Ashgate, 2007.

Laird, Paul, Towards a History of the Spanish Villancico, Warren, Harmonie Park Press, 1997 (Detroit monographs in musicology/Studies in music, 19).

Llergo Ojalvo, Eva, El villancico en la Real Capilla de Madrid en el siglo XVII: dimensión genérica, espectacular y social, Santander, Real Sociedad Menéndez Pelayo, 2017.

López Guil, Itziar, Poesía religiosa cómico-festiva del bajo Barroco español, Berna, Peter Lang, 2011.

Mendoza, fray Íñigo de, Cancionero, ed. Julio Rodríguez Puértolas, Madrid, Espasa Calpe, 1968.

Rodríguez, Pablo L., «"Sólo Madrid es Corte": Villancicos de las Capillas Reales de Carlos Il», Artigrama, 12, 1996-1997, pp. 237-256.

Rodríguez, Pablo L., «Música, devoción y esparcimiento en la capilla del Alcázar Real (Siglo XVIII): los villancicos y tonos al Santísimo Sacramento para Cuarenta Horas», Revista Portuguesa de Musicología, 7-8, 1997-1998, pp. 31-46.

Rodríguez, Pablo L., Música, poder y devoción. La Capilla Real de Carlos II (16651700), tesis doctoral inédita, Zaragoza, Universidad de Zaragoza, 2003, 2 vols.

Tomassetti, Isabella, Mil cosas tiene el amor. El villancico cortés entre Edad Media y Renacimiento, Kassel, Reichenberger, 2008.

Torrente, Álvaro, «The Villancico in Early Modern Spain: Issues of Form, Genre and Function», Journal of the Institute of Romance Studies, 8, 2000a, pp. 57-77.

Torrente, Álvaro, «Las secciones italianizantes de los villancicos de la Capilla Real, 1700-1740», en La música en España en el siglo XVIII, ed. Juan José Carreras y Malcolm Boyd, Madrid, Cambridge University Press, 2000b, pp. 87-94.

Torrente, Álvaro, «Function and liturgical context of the villancico in Salamanca Cathedral», en Devotional Music in the Iberian World, 1450-1800. The Villancico and Related Genres, ed. Tess Knighton y Álvaro Torrente, Aldershot, Ashgate, 2007, pp. 99-148.

Torrente, Álvaro, «El villancico religioso», en Historia de la Música en España e Hispanoamérica. Vol. 3: La música en el siglo XVII, ed. Álvaro Torrente, Madrid, Fondo de Cultura Económica, 2016, pp. 435-530. 